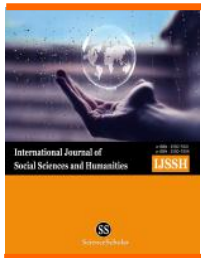

International Journal of Social Sciences and Humanities

Available online at http://sciencescholar.us/journal/index.php/ijssh

Vol. 1 No. 2, August 2017, pages: 1 9

e-ISSN: 2550-7001, p-ISSN: 2550-701X

http://dx.doi.org/10.21744/ijssh.v1i2.26

\title{
Teachers' Perception on the Implementation of the Assessment Process in 2013 Curriculum
}

\author{
CrossMark \\ Wayan Maba ${ }^{a}$ \\ Article history: Received 2 February 2017 ; Accepted in revised form 5 July 2017 ; Approved 8 July 2017 ; \\ Available online 1 August 2017
}

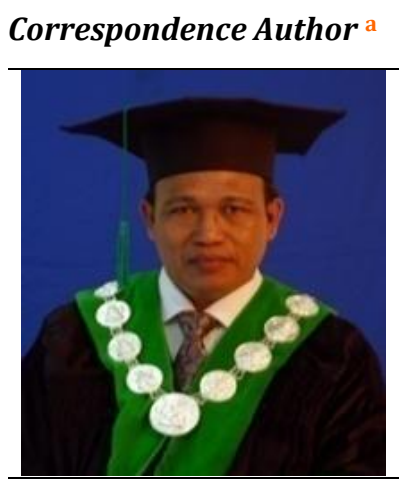

Keywords

Assessment Process;

Curriculum;

Implementation;

Perception;

Teachers;
Abstract

This study aims to describe the teachers' perception on the implementation of the assessment process in 2013 curriculum. This research is a qualitative descriptive research. The subjects of the research are the Elementary school principals and elementary school teachers in Denpasar. Research data were collected through in-depth interviews, observation, and documentation which were analyzed descriptively by using the interactive technique. The interactive analysis was done by collecting data, data reduction, data presentation, and conclusion. The results of data analysis showed that the teachers prepared the lesson plans prior to implementing the teaching and learning processes in the classroom. The lesson plans consist of the rubric of attitude assessment, knowledge assessment, and social assessment. The attitude competence assessment consists of spiritual and social attitudes. The assessment of the attitude competence is done by doing observation, self-assessment, peer assessment, and teacher's journal. The assessment of knowledge competence was done by administrating written test, oral test, and also written an assignment. The students' competencies were assessed by conducting performance assessment. The results of the assessment were written descriptively on the students' learning report by describing the student's ability to detail. Most teachers stated that the assessment in 2013 curriculum is quite good because it provides an attitude assessment, including the aspect of the spiritual and social, knowledge aspects, and skills aspects. There were some obstacles found by teachers in conducting the assessment, such as, limited time that teachers have in observing students' social attitudes and writing the results of the assessment that require a lot of time to describe the students' abilities.

Professor in education psychology in Mahasaraswati University of Denpasar. 
e-ISSN : 2550-7001, p-ISSN : 2550-701X@ Copyright 2017. The Author. SS Journals Published by Universidad Técnica de Manabí.

This is an open-access article under the CC BY-SA 4.0 license

(https://creativecommons.org/licenses/by-sa/4.0/)

All rights reserved.

\section{Contents}

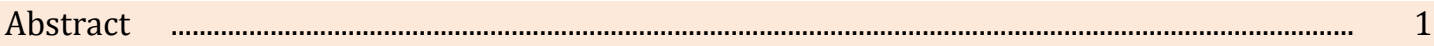

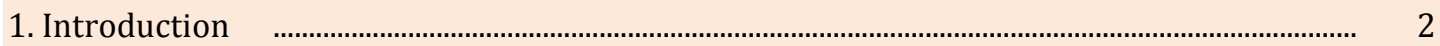

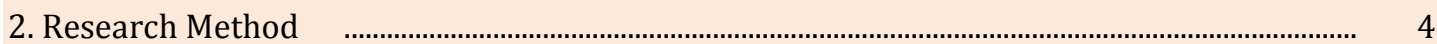

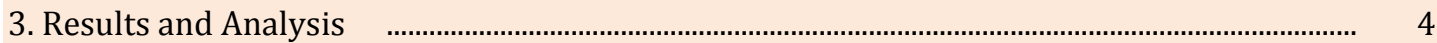

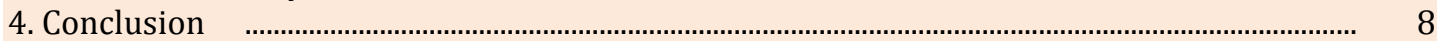

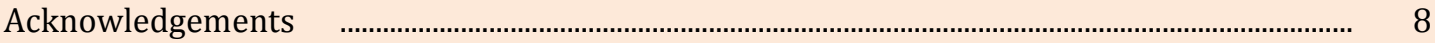

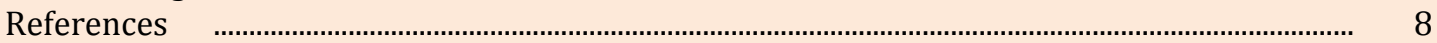

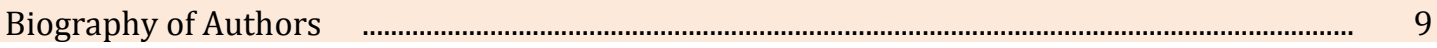

\section{Introduction}

Assessment aims to ensure that the process and performance achieved by the students are in accordance with the plan and objectives (Mulyasa, 2014: 136). Assessment is one of the important aspects of learning. By conducting the assessment, the students can develop their potential optimally, because the number of students' low score or below the standard will affect the effectiveness of learning as a whole. Therefore, the assessment of learning should be done continuously, to know and monitor the changes and progress achieved by learners as well as to score the student's performance, which commonly done by assessing the students' learning outcomes (Taras, 2005 \& Wojtczak, 2002). The assessment of learning outcomes is absolutely done in accordance with existing provisions or norms that have been determined.

According to Law number 20 year 2003 regarding National Education System in article 1 point 1 states that "Education is a conscious and planned effort to create an atmosphere of learning and learning process so that learners actively develop their potential to have spiritual power of religion, self-control, personality, intelligence, Noble, and necessary skills of himself, society, nation, and state ". The implementation of the 2013 curriculum has been implemented by teachers from elementary to senior high school level. In the 2013 Curriculum, students are no longer as the object of learning, but students are the main actors of learning (students' center). In this case, the students become the subjects of learning by participating in developing themes and materials in the learning process. By focusing the learning activities on the students' participation, the content standards, process standards and graduate competency standards, and even assessment standards have been changed. In this curriculum, the assessment implementation includes; assessing the students' attitude, knowledge, and skills for each level of education during the learning processes (assessment process) and after the learning processes (assessment of learning outcomes).

The assessment implementation in teaching and learning will determine the success of the teaching and learning process (Widiastuti, 2016). Assessment which is conducted in the learning process is not only measuring the student's learning ability but also understanding the weaknesses of the student in learning, in order that the teachers can modify their teaching strategy to achieve the learning objectives (Marshal, 2005; Box, Skoog \& Dabbs, 2015; Widiastuti, 2017). The assessments which are conducted by the teacher in the classroom are strongly influenced by their perception regarding the process of the assessment itself. The diversity of the teachers' understanding of assessments in the 2013 curriculum certainly affects the teachers' perceptions of the assessments practices.

Perception is a response or opinion that is a process of the individual to receive or know about something through the senses. A number of factors may play a role in shaping teachers 
perceptions of classroom assessment. One of the most influential factors is the teachers' orientation to assessment as a discipline. The process of receiving stimulus between an individual with other individuals is different according to internal factor and external factor of each individual. Differences in understanding resulted in differences in perceptions between individuals with one another. Teacher's perception is the response of a professional educator about what is experienced in educating, teaching, guiding, directing, training, assessing and evaluating children of the aged child in the educational pathway that is influenced by the beliefs and feelings of the educator. This difference in understanding will cause different judgments of each teacher.

The different of the teachers' understanding influence the way of the assessment implementation (Widiastuti, 2017). The different way of assessment can lead to different perceptions which are very subjective. Different perceptions may affect the teacher's behavior on the judgments they made. Teacher' perceptions can be divided into two categories namely positive perceptions and negative perceptions. Positive or good teacher perception will become a good foundation in responding to all matters relating to the assessment process in the 2013 curriculum, including on the readiness of assessment implementation in 2013 curriculum. Meanwhile, a negative perception of the assessment will become a barrier of the conduction of rules relating to the process Assessment in 2013 curriculum. Assessment of the students' learning outcomes includes the attitudes competence, knowledge, and a balance of skills, so it can be used to determine the relative positions of each learner to against the standards that have been applied. The scope of the assessment refers to the scope of the subject matter, subject competencies, competency of content, program competencies, and processes. (Minister of Education Regulation number 66 the year 2013).

Learning Assessment is inseparable from the role of educators. Teachers have freedom in determining the assessment techniques to be used. From preliminary interviews and observations conducted by the authors of some Elementary teachers in Denpasar, there are various responses related to the assessment process in 2013 curriculum. Some teachers who welcomed the implementation of the assessment of 2013 curriculum, they assumed that the assessment process is complicated, even who have not understood the assessment in the 2013 curriculum. From the preliminary study, some teachers have different perceptions of justice and arouse questions. Are all teachers familiar with the assessment of the 2013 curriculum? Have teachers implemented the assessment in their teaching and learning process? What do Indonesian teachers think about assessment in the 2013 curriculum? According to the results of the preliminary interviews that have been done, the teachers stated that the difficulty in applying the 2013 curriculum is at the time of assessment implementation. There are not many teachers understand about the assessment in the 2013 curriculum and they also stated that the 2013 curriculum assessment is too complicated to implement. Based on the background that has been described above, the research focus on this research is about "The perception of the elementary school teachers in implementing assessment process in 2013 curriculum. Based on this general problem, some problems relating to teachers' perceptions of authentic judgment may be formulated, including 1 . what is the teachers' perception of the assessment process in the 2013 curriculum? 2. are there any constraints faced by the teachers in implementing assessment in 2013 curriculum? The aim of the study is describing the elementary school teachers' perceptions in implementing the assessment process in 2013 curriculum in several elementary schools in Denpasar. The results of this study are expected to provide theoretical benefit: (1) Become references for the development of science regarding the teachers' perception of the assessment process. Practical benefits: (1) For the Principal, the result of the study can be used as a source of information that can be used as materials to improve the quality of teaching and learning process. (2) For the teachers, the results of this study are expected to serve as a reference technique to improve the teachers' competence, especially the assessment process. (3) For

Maba, W. (2017). Teacher's perception on the implementation of the assessment process in 2013 curriculum. International Journal of Social Sciences and Humanities, 1(2), 1-9. https://doi.org/10.29332/ijssh.v1n2.26 
students and other researchers, this research can be used as material comparison and reference in relevant research.

\section{Research Method}

A qualitative approach was used to analyze data of the study. In this study, the data about the teacher's perception of the assessment process in the 2013 curriculum was explained descriptively. This type of research was descriptive qualitative research because it described the teacher's perception of the assessment process in the 2013 curriculum and also the constraints encountered by the teachers in implementing the assessment. This research was conducted in several elementary schools in Denpasar. The data was collected by doing observation and in-depth interview with the principal and the elementary school teachers in Denpasar. The participants of the study were chosen by doing random sampling technique in order to get various data regarding the teachers' perception on the implementation of the assessment process. The data was collected by conducting in-depth interviews, in relax situation to the teachers and principals to get data related to the teachers' perceptions and constraints faced by the teachers in implementing the assessment process in 2013 curriculum. The interview guide was the instrument used to collect data related to teachers' perceptions of the 2013 curriculum assessment process. The other data was collected by doing direct observation. Observation is a method of data collection using observation of research object (Riyanto, 2012). In this study, researchers conducted observations on assessment activities during the teaching and learning process in the classroom. Observations were conducted to find out the implementation of the 2013 curriculum assessment conducted by teachers in the classroom. List of observations was the instrument used to collect data on the implementation of the assessment in accordance with 2013 curriculum. Document study was conducted in order to find the data regarding the teachers' documentation. Documentation method means how to collect data by recording the data that already exist. Documentation was a way of collecting data by collecting and analyzing documents that were considered important in the research undertaken. In this study, the documents used were lesson plans and report cards (report book).

In the data analysis, a detailed description of teachers' perceptions was analyzed. The data obtained from interviews were transcribed and then interpreted. The transcription of the interview and observation were coded into categories. Then the categorized data were analyzed and described argumentatively.

\section{Results and Analysis}

The 2013 curriculum was designed to improve the previous Indonesian education curriculum. In learning activities, the focus is using thematic learning. Most of the elementary school teachers in Denpasar have implemented the lessons according to 2013 curriculum. In this case, the teachers were able to explore about learning materials. In learning local content, English and Balinese language are added. Some schools even added Mandarin as an extra language subject. In the process of conducting the assessment, the focus of the assessment conducted by the teachers was not only based on results or targets, but the emphasis was on the process of learning conducted in the classroom. The learning process was focused on cognitive, affective, and psychomotor. Therefore the implementation of the assessment conducted by teachers includes four core competencies that were the spiritual, social, knowledge, and skills. Assessment results were written in the report notes in one semester. The teacher used a numeric value then converted to a letter grade, and then given an explanation in the description form. There were several ways performed by teachers in the city of Denpasar in converting students' grades. Some teachers converted students' grades by using their self-downloaded application systems.

To get a good understanding of the 2013 curriculum, some schools have provided teacher training or workshop on the implementation of the 2013 curriculum, how to implement the curriculum, the curriculum implementation and the way of assessing the students' 
achievement. There were some obstacles encountered by teachers and schools in the implementation of assessments in 2013 curriculum. Many things were done by teachers to reduce the constraints faced related to the implementation of the 2013 curriculum assessment. Teachers who did not really understand about the implementation of 2013 curriculum were discussed their problems with their peers. They discussed all matters that have not been understood by other teachers. Many obstacles faced by teachers regarding the implementation of the assessment in 2013 curriculum. Most teachers judge that the implementation of the assessment should be undertaken in many processes. The 2013 curriculum is a curriculum of thematic learning, no separation per subject. All subjects were interrelated that were limited by a theme.

According to teacher A, the implementation of the 2013 curriculum required creativity from both teachers and students. All learning activities were focused on the themes as well as the focus of the assessment refers to all aspects of the curriculum.

\footnotetext{
"The 2013 curriculum is appropriate for elementary school children because the themes are interesting and interrelated. All subjects are theme-based and tailored to the subjects taught."
}

He further stated that the assessment process in the 2013 curriculum assessed subjects of learning from all aspects, such as the spiritual, social, knowledge and skills aspects. Teacher A also added that the lessons in the 2013 curriculum were implemented by using thematic so that assessment was also carried out according to the theme being taught. However, teachers were expected to assess lessons based on subjects. In the assessment implementation, the teachers assessed every theme taught and they can determine the result of the assessment for every subject. Regarding the daily test, teacher B stated that;

\footnotetext{
"Every daily test which is conducted according to 2013 curriculum consists of several kinds of subjects. Meaning that a test contains all subjects from science, social, and Bahasa Indonesia."
}

In this case, the teacher was expected to be able to assess the results of the test and assessed the students' basic competencies. Teachers should have the ability to make tests by integrating all subjects into one test, as well as providing assessments according to the existing subjects. The ability of teachers in preparing and implementing assessment was inseparable from the preparation that teachers do prior to their teaching in the classroom. Teacher C, for example, before teaching, he always made lesson plans completed with a rating rubric. In his teaching, scientific approach was used to teach in the class. He always asked students to observe, ask, try, give reasons, and communicate according to the steps in the teacher's book. On the other hand, to assess the spiritual and social aspects of the students, the teacher observed the students' behavior every day. The assessment was also done by conducting self-assessment, peers assessment, and teacher records. Furthermore, to assess the students' aspects of knowledge or ability, the assessment was conducted by doing daily tests, a middle test and also a final test. The performance test was also done by the teacher to know the student's competence.

Teacher C had previously received training from Government about 2013 curriculum, learning material development, how to design syllabus and lesson plans, and administer assessment according to 2013 curriculum. But he had little understanding in writing the student's learning outcomes in the student report book. The form of student learning outcomes in 2013 curriculum is in the form of description. In this case, the teacher should describe the student learning outcomes descriptively in detail.

"The way in writing the students' result of the study in 2013 curriculum is described descriptively like a very simple kindergarten report. Only 15 sheets, but the assessment is

Maba, W. (2017). Teacher's perception on the implementation of the assessment process in 2013 curriculum. International Journal of Social Sciences and Humanities, 1(2), 1-9. https://doi.org/10.29332/ijssh.v1n2.26 
very complicated. I am required to describe the results of students' learning, so it takes more time in describing my students' learning ability."

In addition, in writing the students' learning outcomes, the teacher took more time to describe the ability of students descriptively. Other obstacles encountered by the teacher in administering assessment were the teacher should assess the students' attitudes, knowledge, and skills in some criteria every day in limited time.

\footnotetext{
"Every day I have to assess all the aspects that should be assessed for my students. There are a lot of things to be assessed. This takes a long time, especially the number of students in a class are more than 35 students. So sometimes the assessment is not done and piled up."
}

The same thing was also conveyed by teacher D. He had difficulties and constraints when he assessed all those aspects. Lack of time and a big number of students made the process of assessment was not optimally administered. The teacher also had to provide plenty of time to write students' learning outcomes in the study report book. There was also no fixed rule from the government for assessment in 2013 curriculum.

\footnotetext{
"I do the assessment and write down student learning outcomes by using the standard assessment that I download by myself with other teachers. Schools search the form of the assessment form from their own application, create their own forms, and print themselves. If there is a standard or there is a definite assessment format from the Government, it will be more effective, the teacher just puts the mark in the assessment form".
}

According to him the assessment process in 2013 curriculum was complicated. Every day he should assess the students in some criteria. He also stated that he assessed from core competence one to core competence four but the assessment system was simpler because there was a certain standard of assessment from the Government. According to teacher E, the 2013 curriculum was identical with thematic. The main subjects are such as Indonesian language, national constitution, Mathematics, Science, and social into one theme. All subjects were linked to a single theme. Assessment in 2013 curriculum consisted of spiritual assessment, social attitude assessment, knowledge assessment, and skills assessment. Each aspect of assessment indicates each indicator.

Assessment in the 2013 curriculum was identical to the description which was more focused on building up the students' characters. Teacher E previously received training from the school. In the training, He learned how to make lesson plans, how to teach, and how to implement the assessments according to 2013 curriculum. He always makes lesson plans with the rubric of assessment before teaching. On the other hand, in assessing the social and spiritual aspects of the students, the teacher observed the students' behavior during the learning activity. In addition, the assessment of attitude aspect was also done by doing peer assessment, self-assessment, and journal teacher notes. For the assessment of knowledge aspect, the teacher E took the students' grade by giving exercises which usually taken on Saturday. He took the grade for every sub theme. For the performance aspects, the teacher took the students' grade by telling the students to perform their ability in their classroom activities. According to him the obstacles in the assessment of the 2013 curriculum were on the skills assessment. There were a lot of performance assessment should be taken by the teacher, so he had lacked time to carry it out. The assessment process was not finished at that time and it should be continued at the next meeting. The form of reporting the result of the assessment was still quite complicated and should be more simplified.

The 2013 curriculum assessment consists of 6 subjects; each subject must be completed at every meeting. In a week there is a sub theme should be finished. While in a lesson there are various performance that should be conducted in insufficient time. The complicated 
implementation of the 2013 curriculum also was stated by teacher F. Teacher F stated that the assessment process in 2013 curriculum was very complicated.

"The 2013 curriculum is very difficult; the time required is quite a lot, better adapted to the time allocation. Assessment for every student cannot be done one by one. I am confused to do the performance assessment and complete the assessment process only in a day."

According to teacher G, the 2013 curriculum was a curriculum in which thematic method was the main focus. It's not per subject anymore. Subjects were interrelated in a theme. The implementation of 2013 curriculum gave the opportunity to the students for being more creative. They can express their expression well and they can participate in the learning activities. The assessment focus was also very complete. It was not only assessing the students' cognitive but also assessing the students' attitude, behavior, and character. There were four core competencies such as; spiritual, social, knowledge, skills and attitude aspects.

\begin{abstract}
"The 2013 curriculum assessment is broader and more detailed. The score in 2013 curriculum is different which more in the context of its description is only. In scoring, there is no difference. The child gets the number scores. But by the teachers processed into the description"
\end{abstract}

Teacher G received training from the Government and from school. In the training, he got more information about 2013 curriculum including the assessment implementation. Before teaching the teacher $\mathrm{G}$ always made lesson plans that contain with assessment rubric. $\mathrm{He}$ implemented his teaching process in form of student centered learning. The students were actively encouraged in every lesson to be active in discussion and questioning and answering. He took daily spiritual and social score by observing student behavior and occasionally told students to do peer assessment and self-assessment. For the assessment of knowledge, he conducted exercises in the form of question and answer direct test. For assessing the students' skills, the assessment is administered during the teaching activities by observing the students' performance. The teacher G also found some barriers to the assessment implementation. He mentioned that the attitude and spiritual assessment should not be conducted every day because this wasted a lot of time. He also stated that the students' attitudes were not changing every day and it was better to administer the assessment once a week. Moreover, in writing the students' report was very complicated, because the process was too long and the report book of the students' ability did not make the parents satisfied because there was no numerical grade in it. They did not know their students level. On the other hand, he also stated that the assessment in the 2013 curriculum was quite good. The assessment was complete. The teachers were able to assess the students' spiritual activity, social, knowledge, and skill aspects.

In the observation, the researcher carefully observed the ongoing learning activities. Researcher focused on the teachers' ability to apply thematic lessons and conducted assessments in the 2013 curriculum. The teachers have already made lesson plans before teaching. The lesson plan was supplemented by an assessment rubric. Assessments are about the students' attitudes, knowledge, and skills. The material taught was in accordance with the lesson plan. Learning activities were carried out in accordance with the steps in the lesson plan and teacher book. Most teachers apply scientific learning (observing, asking, trying, experimenting, reasoning, and communicating). Learning model used in the teaching and learning process was lecture, question and answer and discussion. The attitude assessment was administered to carefully observe the students' attitude, confidence, and responsibility by looking at the changes in student behavior.

Knowledge assessment was done in the written form. The instrument used in assessing the student's knowledge was essayed test. The assessment forms, such as checklists consisted of some criteria and scores. The score consisted of scores 1 to 4 , where score 1 was excellent, score 2 was good, score 3 was sufficient, and score 4 needed guidance. Teachers provide

Maba, W. (2017). Teacher's perception on the implementation of the assessment process in 2013 curriculum. International Journal of Social Sciences and Humanities, 1(2), 1-9. https://doi.org/10.29332/ijssh.v1n2.26 
enrichment for students who have completed the study and provide a remedial test for the students whose grade was not completed.

\section{Conclusion}

Based on the results of the research and the discussion that has been presented, the following conclusions could be drawn:

The teachers' learning preparation was in accordance with the 2013 curriculum. The lesson plans written by the teachers provide a rubric for assessing the students' attitudes, knowledge, and social. Teachers have been conducting the assessment of attitude competence which was divided into 2, namely spiritual and social attitudes. Assessment of attitude competencies was done by doing with observation techniques, self-assessment, peer assessment, and journal teacher records. The teacher carried out the process of assessing the students' knowledge competence in the form of written test, oral test, question and answer test and also daily assignment. Teachers have conducted the skills competency assessment process with performance assessment techniques. The report made by the teacher according to the rules of the report in 2013 Curriculum.

The report was in the descriptive score. In making the report, the teachers used their own applications downloaded by schools. There was a common opinion that the assessment of the 2013 curriculum was good, the assessment aspect was complete. The assessments are concerning the aspects of attitude such as spiritual and social, aspects of knowledge, and aspects of skills. There were some obstacles such as; the steps to make the report were still complicated. The application used was not simple. It should be made per sub theme not per learning subject because the time to do the assessment is not sufficiently allocated.

\section{Acknowledgement}

The authors would like to express his profound gratitude to all educators, teachers, and researchers for their help in conducting and writing this study. Deep sincere gratitude also goes to the government authority of Education in Bali Province for the opportunity to study their education system. Special thanks are dedicated to all friends for their support, their contribution, and their valuable input during the writing of this paper. Sincere gratitude also goes to the editors who have reviewed and approved this article to be published.

\section{References}

1. Adetunji, A. T., Adetunji, A. V., Adeleke, E. O., \& Madubuike, S. C. (2017). Deregulation: The Effect of Market-led Approach to Nigerian Universities Management. International Journal of Social Sciences and Humanities (IJSSH), 1(1), 1-8.

2. American Educational Research Journal Vol. 52, No. 5, pp. 956-983. Educational Research. Surakarta: Faculty of Teacher Training and Education University of

3. Amerta, I. M. S. (2017). The Role of Tourism Stakeholders at Jasri Tourism Village Development, Karangasem Regency. International Journal of Social Sciences and Humanities (IJSSH), 1(2), 20-28.

4. Astawa, I. N., Mantra, I. B. N., \& Widiastuti, I. A. M. S. (2017). Developing Communicative English Language Tests for Tourism Vocational High School Students. International Journal of Social Sciences and Humanities (IJSSH), 1(2), 58-64.

5. Basak, A., \& Khanna, K. (2017). A Study on the Selection Criteria of Different Hotels of Delhi NCR in Accordance to the HR Policies and Market Trends. International Journal of Social Sciences and Humanities (IJSSH), 1(1), 27-38.

6. Billaiya, R., Malaiya, S., \& Parihar, K. S. (2017). Impact of Socio Economic Trends on Students in Quality Education System. International Journal of Social Sciences and Humanities (IJSSH), 1(1), 16-20.

7. Black, P. Harrison, C. Lee, C., Marshall, B., and William, D. 2004. Working inside the box: Assessment for Learning in the classroom. Phi Delta Kappan. Volume 86, number 1. Pages 8-21.

8. Box, C., Skoog, G., Dabbs, J.M, 2015. A Case Study of Teacher Personal Practice Assessment Theories and Complexities of Implementing Formative Assessment. 
9. Cedeño, M. L. D., Arteaga, M. G. D., Pérez, A. V., \& Arteaga, M. L. D. (2017). Regulatory Framework for Renewable Energy Sources in Ecuador Case Study Province of Manabí. International Journal of Social Sciences and Humanities (IJSSH), 1(2), 29-42.

10. Gámez, M. R., Pérez, A. V., Será, A. S., \& Ronquillo, Z. M. (2017). Renewable Energy Sources and Local Development. International Journal of Social Sciences and Humanities (IJSSH), 1(2), 10-19.

11. Ghosh, C. (2017). A Study on-Evaluating Marketing Strategies Adopted by Home Appliance for Economic Development in India. International Journal of Social Sciences and Humanities (IJSSH), 1(1), 9-15.

12. Maba, W. (2017). Teacher's Perception on the Implementation of the Assessment Process in 2013 Curriculum. International Journal of Social Sciences and Humanities (IJSSH), 1(2), 1-9.

13. Maba, W., \& Mantra, I. B. N. (2017). An Analysis of Assessment Models Employed by The Indonesian Elementary School Teachers. International Journal of Social Sciences and Humanities (IJSSH), 1(1), 39-45.

14. Miles, M. B., \& Huberman, A.M. 1994. Qualitative data analysis. Thousand Oaks, CA: Sage.

15. Muhammadiyah Surakarta Sani and Imas. 2014. McMillan, J. H., Venable, J. C., \& Varier, D. 2013. Studies of the Effect of Formative Assessment on Student Achievement: So Much More is Needed. Practical Assessment, Research \& Evaluation, 18(2), 1-15.

16. Mulyasa. 2013. Curriculum Development and Implementation 2013. Bandung: PT Remaja Rosdakarya Regulation of Minister of Education and Culture No. 66 the year 2013

17. Nespor, J. 1987. The Role of Beliefs in The Practice of Teaching. Journal of Curriculum Studies, 19(4), 317-328.

18. Newton, P. E. 2007. Clarifying the Purposes of Educational Assessment. Assessment in Education: Principle Policy \& Practice, 14(2), 149-170. Implementation of the 2013 Curriculum Concepts and Implementation. Surabaya: Kata Penet Tim Preparation Dictionary of Indonesian language center 2005.

19. Rahman, N. F., Babu, R \& Ashrafuzzaman, M. 2011. Assessment and Feedback Practices in the English Language Classroom. Journal of NELTA, Vol. 16 No. 1-2

20. Riyanto, Orphans. 2012. Research Methodology. Bandung: SICRubiyanto, Rubino. 2013.

21. Shepard, L. A. 2005. Linking Formative Assessment to Scaffolding. Educational Leadership, 63, 66-70.

22. Sri Widiastuti, I.A.Md. 2016. EFL Teachers' Beliefs and Practices of Formative Assessment to Promote Active Learning. The ASIAN EFL Journal. Volume 3.

23. Sri Widiastuti, I.A.Md. 2017. Teachers' Understanding of Formative Assessment. Jurnal Bahasa dan Seni. Vol 45, No 1 Juni 2017.

24. Suparsa, I. N., Mantra, I. B. N., \& Widiastuti, I. A. M. S. (2017). Developing Learning Methods of Indonesian as a Foreign Language. International Journal of Social Sciences and Humanities (IJSSH), 1(2), 51-57.

25. Suryasa, I. W., Prayoga, I. G. P. A., \& Werdistira, I. W. A. (2017). An Analysis of Students' Motivation Toward English Learning As Second Language Among Students In Pritchard English Academy (PEACE). International Journal of Social Sciences and Humanities (IJSSH), 1(2), 43-50.

26. Taras, M. 2005. Assessment -Summative and Formative- Some Theoretical Reflections. British Journal of Educational Studies, 53/4, 466-478.

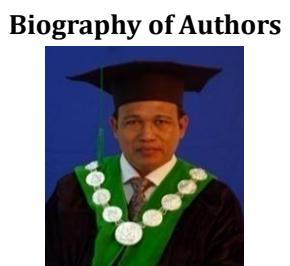

Prof. Dr. Wayan Maba is a Professor in education psychology in Mahasaraswati University of Denpasar. He is a lecturer on diverse subjects related to educational fields. He is currently teaching the students of undergraduate and post graduate study program in Maharaswati University and other universities in Bali. Prof. Dr. Wayan Maba has conducted extensive research in Education system, curriculum, and assessment and other related topics and his papers have been published nationally and internationally in various reputable journals.

Maba, W. (2017). Teacher's perception on the implementation of the assessment process in 2013 curriculum. International Journal of Social Sciences and Humanities, 1(2), 1-9. https://doi.org/10.29332/ijssh.v1n2.26 